\title{
Water Quality of Sinamar River Lima Puluh Kota District West Sumatera Basedon Structure of Microalgae Periphyton as Bioindicator
}

\author{
Reni Ekawaty ${ }^{1}$, Harmailis $^{1}$, Abizar $^{2}$
}

\begin{abstract}
Sinamar River is one of the rivers in Lima Puluh Kota District, that have important functional. This river is used as irrigation, bathing and washing, and husbandaries. There are many human activities as long as this river such as residents, industries, tradisional markets, and agricultural. The objective of this studi is to know the level of Sinamar River pollution based on microalgae periphytons communities. The samples was taken in 8 stations. The result are microalgae periphytones in Batang Sinamar founded 24 spesies, Cyanophyta (3 spesies), Chloropyhta (7 spesies), Chrysophyta (12 spesies), Euglenophyta (2 Spesies). Diversity .indeks is about 2,51-2,75 and saprophyt index is about 0,9-1,3. This is indicated Batang Sinamar contaminated lightly. Based on water quality, Batang Sinamar has DO 6,88 $-8,33 \mathrm{mg} / \mathrm{L}$, BOD ${ }_{5} 0,14$ $-1,60 \mathrm{mg} / \mathrm{L}$, COD $0,8-10,4 \mathrm{mg} / \mathrm{L}$, Amoniak < 0, $14 \mathrm{mg} / \mathrm{L}$, TSS 0 , $058-0,16 \mathrm{mg} / \mathrm{L}$, and $\mathrm{pH} 6,52-7,37$. All of this parameters still in range of Indonesian Goverment Regulation No 82/ 2001.
\end{abstract}

Keywords-bioindicator, microalgae, periphyton, Sinamar River, Water Quality.

\section{INTRODUCTION}

$\mathrm{S}^{\mathrm{N}}$ INAMAR River is one of the rivers that have important functional. This river is used as irrigation, bathing and washing, and husbandaries. In ecology, this river is habitat of local fishes such as gariang, barau, bauang, mansai. Their populations more decreasing now. Pollution make water quality decreasing in physi, chemestry and biology. Physic and chemestry research have weakness. It is affected by some factors, one of them is debite. It's different debite in rainy and dry seasons. In example, in dry season the river is look clearly whilst the river is look turbid in rainy season. Nowadays, water quality monitoring focus to biota, it is more explisit to explain the water pollution. Biota will affect direclty to along term pollution.

One of biota is periphyton. Periphyton have important functions in aquatic ecosystem and as primer produsen. Periphyton can use as bioindicator, that there is a change in aquatic ecosystem, due to unbalanced ecosystem [1]; [2].

Manuscript received September 14, 2017. This work was supported in part by Indonesian Ministry of Research, Technology and Higher Education and Payakumbuh of Agriculture Polytechnic

Reni Ekawaty is with Agricultural Water Management Study Program, Agricultural Technology Department, Payakumbuh Agricultural Polytechnic, West Sumatera, Indonesia (e-mail: ekawatyreni@ yahoo.co.id).

Harmailis is with Agricultural Water Management Study Program, Agricultural Technology Department, Payakumbuh Agricultural Polytechnic, West Sumatera, Indonesia (e-mail: harmailis_chaniago@yahoo.com)

Abizar is with Biology Study Program, STKIP Padang, West Sumatera, Indonesia (e-mail: abhie_zar@yahoo.co.id).
Some organisms of periphyton are tolerant and have different responses to water quality changing.

Microalgae periphyton's abundance can use as bioindikator that there is a wa ter quality changing, due to unbalanced, effect from contaminant. It is base on diveristy, composition, and dominant of periphyton in the river.

The objective of this study is to know water quality of Sinamar River base on stucture of microalgae periphyton.

\section{Methodology}

The study has been done from July to September 2017 in 8 stations along as Sinamar River (Figure 1).

Microalgae periphyton has taken by brushed stones or other substrate by wire brush. The product from brushes took into sample bottles and given formaline $30 \%$. Water samples have been taken in the same location. The microalgae periphyton and water samples will analyzed in laboratories

Periphyton will identification and analyzed the diversity by using Shannon-Wiener Index:

$$
\mathrm{H}^{\prime}=\sum_{i=1}^{s}\left(\mathrm{Pi} \log _{2} \mathrm{Pi}\right)
$$

Description: $\mathrm{H}^{\prime}=$ Shannon-Wiener Indeks, $\mathrm{Pi}=\mathrm{ni} / \mathrm{N}, \mathrm{ni}=$ number of individual spesies- $\mathrm{i}^{\text {th }}, \mathrm{N}=$ total number of individual.

Saprobic index waqs determined using the following formula :

$$
\mathrm{X}=\frac{C+3 D-B-3 A}{A+B+C+D}
$$

Description: $\mathrm{X}=$ saprobic index, $\mathrm{A}=$ number of organisms Cyanophyta, $\mathrm{B}=$ number of organism Euglenophyta, $\mathrm{C}=$ number of organisms Chrysophyta, $\mathrm{D}=$ number of organisms of Chlrorophyta.

\section{RESULT AND DISCUSSION}

The identification of periphyton in Sinamar River have founded 24 spesies. Cyanophyta 3 spesies, Chlorophyta 7 spesies, Bacillariophyta 12 spesies, and Euglenophyta 2 spesies. The list of periphyton is presented in Table 1. 


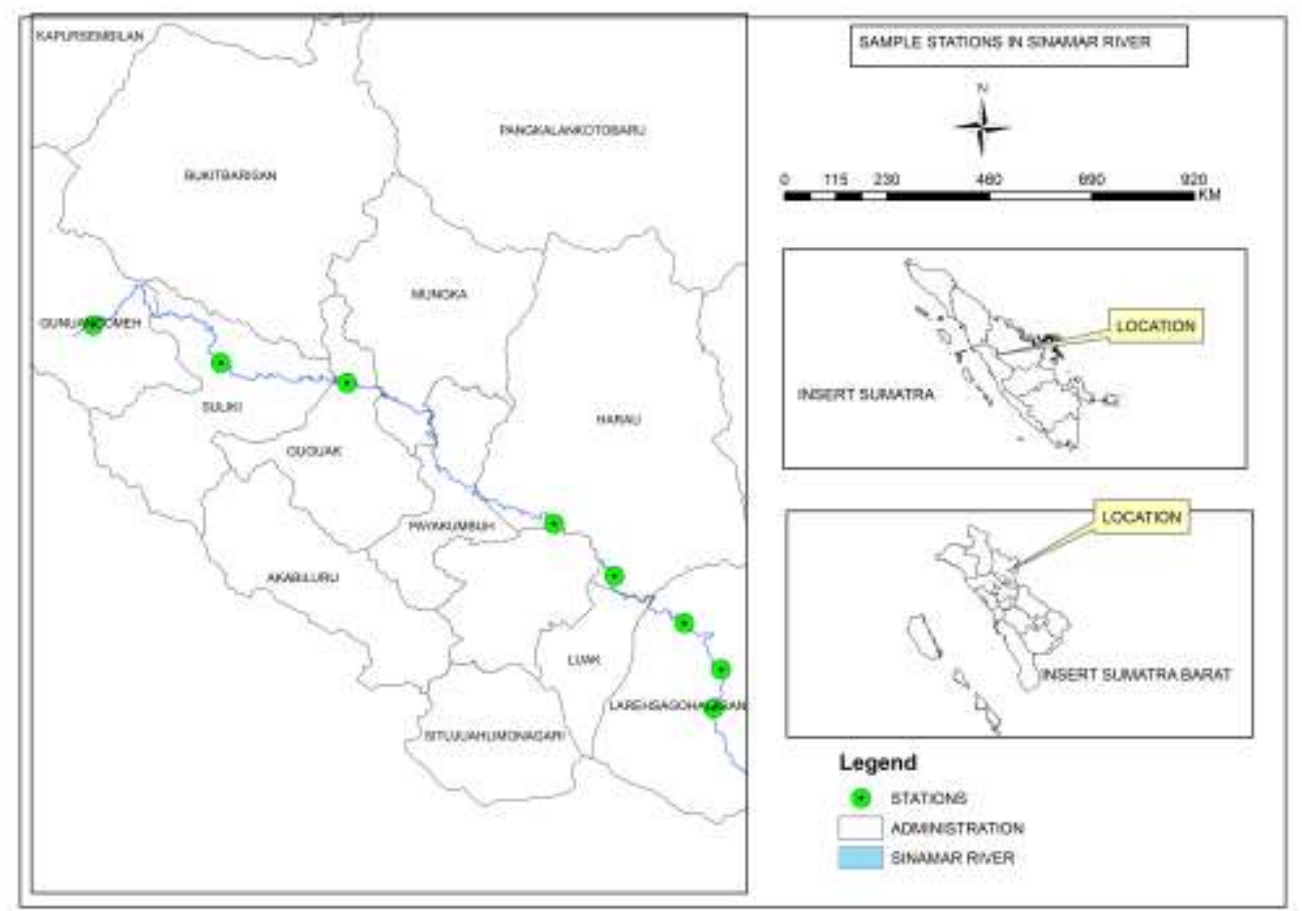

Fig 1. SAmple Stations At SinAmar River

TABLE I:

PERIPHYTON IDENTIFICATION IN SINAMAR RIVER

\begin{tabular}{|c|c|c|c|c|c|c|c|c|c|}
\hline \multirow{2}{*}{ No } & \multirow{2}{*}{ Taksa } & \multicolumn{8}{|c|}{ Stations } \\
\hline & & 1 & 2 & 3 & 4 & 5 & 6 & 7 & 8 \\
\hline & Cyanophyta & & & & & & & & \\
\hline 1 & Oscillatoria & $\mathrm{v}$ & $\mathrm{V}$ & $\mathrm{V}$ & $\mathrm{V}$ & $\mathrm{V}$ & $\mathrm{V}$ & $\mathrm{V}$ & $\mathrm{v}$ \\
\hline 2 & Lyngbia & $\mathrm{v}$ & $\mathrm{V}$ & $\mathrm{V}$ & $\mathrm{v}$ & $\mathrm{V}$ & $\mathrm{V}$ & $\mathrm{v}$ & $\mathrm{v}$ \\
\hline 3 & Haphalosiphon & $\mathrm{v}$ & - & - & - & - & $\mathrm{V}$ & - & - \\
\hline & Chlorophyta & & & & & & & & \\
\hline 4 & Oedogonium & $\mathrm{V}$ & $\mathrm{V}$ & $\mathrm{V}$ & $\mathrm{V}$ & $\mathrm{V}$ & $\mathrm{V}$ & $\mathrm{V}$ & $\mathrm{v}$ \\
\hline 5 & Spyrogira & $\mathrm{V}$ & $\mathrm{V}$ & $\mathrm{V}$ & $\mathrm{v}$ & $\mathrm{V}$ & $\mathrm{V}$ & $\mathrm{v}$ & $\mathrm{v}$ \\
\hline 6 & Cladophora & $\mathrm{V}$ & - & $\mathrm{V}$ & $\mathrm{V}$ & $\mathrm{V}$ & $\mathrm{V}$ & $\mathrm{V}$ & - \\
\hline 7 & Closterium & $\mathrm{v}$ & $\mathrm{V}$ & $\mathrm{V}$ & $\mathrm{v}$ & $\mathrm{V}$ & $\mathrm{V}$ & $\mathrm{v}$ & - \\
\hline 8 & Desmidium & $\mathrm{v}$ & $\mathrm{v}$ & $\mathrm{V}$ & $\mathrm{V}$ & - & - & - & $\mathrm{v}$ \\
\hline 9 & Scenedesmus & $\mathrm{V}$ & - & - & $\mathrm{v}$ & - & $\mathrm{V}$ & - & - \\
\hline 10 & Cosmarium & $\mathrm{v}$ & - & - & $\mathrm{V}$ & $\mathrm{V}$ & - & - & $\mathrm{v}$ \\
\hline & Chrysophyta & & & & & & & & \\
\hline 11 & Synedra & $\mathrm{v}$ & $\mathrm{v}$ & $\mathrm{V}$ & $\mathrm{V}$ & $\mathrm{V}$ & $\mathrm{V}$ & $\mathrm{V}$ & $\mathrm{v}$ \\
\hline 12 & Frustullia & $\mathrm{v}$ & - & $\mathrm{V}$ & $\mathrm{v}$ & - & - & - & $\mathrm{v}$ \\
\hline 13 & Cymbella & $\mathrm{v}$ & $\mathrm{v}$ & $\mathrm{V}$ & $\mathrm{V}$ & $\mathrm{V}$ & $\mathrm{V}$ & $\mathrm{V}$ & $\mathrm{v}$ \\
\hline 14 & Navicula & $\mathrm{v}$ & $\mathrm{V}$ & $\mathrm{V}$ & $\mathrm{V}$ & $\mathrm{V}$ & $\mathrm{V}$ & $\mathrm{V}$ & $\mathrm{V}$ \\
\hline 15 & Eunotia & - & - & $\mathrm{V}$ & - & $\mathrm{V}$ & $\mathrm{V}$ & - & - \\
\hline 16 & Pinnularia & $\mathrm{V}$ & $\mathrm{V}$ & $\mathrm{V}$ & $\mathrm{V}$ & $\mathrm{V}$ & $\mathrm{V}$ & $\mathrm{V}$ & - \\
\hline 17 & Gomphonema & $\mathrm{v}$ & $\mathrm{V}$ & $\mathrm{V}$ & - & $\mathrm{V}$ & $\mathrm{V}$ & $\mathrm{v}$ & - \\
\hline 18 & Nitzchia & - & $\mathrm{v}$ & $\mathrm{V}$ & $\mathrm{V}$ & $\mathrm{V}$ & $\mathrm{V}$ & - & $\mathrm{v}$ \\
\hline 19 & Fragillaria & $\mathrm{V}$ & $\mathrm{V}$ & $\mathrm{V}$ & $\mathrm{V}$ & $\mathrm{V}$ & $\mathrm{V}$ & $\mathrm{V}$ & $\mathrm{v}$ \\
\hline 20 & Diploneis & $\mathrm{V}$ & $\mathrm{V}$ & $\mathrm{V}$ & $\mathrm{V}$ & $\mathrm{V}$ & $\mathrm{V}$ & $\mathrm{V}$ & $\mathrm{v}$ \\
\hline
\end{tabular}

\begin{tabular}{|l|l|c|c|c|c|c|c|c|c|}
21 & Surirella & $\mathrm{v}$ & $\mathrm{v}$ & $\mathrm{v}$ & $\mathrm{v}$ & $\mathrm{v}$ & - & $\mathrm{v}$ & $\mathrm{v}$ \\
\hline 22 & Neidium & - & - & - & $\mathrm{v}$ & - & $\mathrm{v}$ & $\mathrm{v}$ & - \\
\hline & & & & & & & & & \\
\hline & Euglenophyta & & & & & & & & \\
\hline 23 & Euglena & - & - & $\mathrm{v}$ & - & $\mathrm{v}$ & - & - & - \\
\hline 24 & Phacus & $\mathrm{v}$ & $\mathrm{v}$ & - & - & - & - & - & $\mathrm{v}$ \\
\hline
\end{tabular}

We can see at Table I, there are many Chrysophyta (diatoms) founded in Sinamar River. These genera are susceptible to environmental change such as physic, chemistry and biology. This changing can come from the people activities like farmings, industries and residents. Wastes from these activities is removed into river and have impact to periphyton. The blooming diatoms have been founded in many research like [2], [3], [4], [5], [6], [7]. Ekwu and Sikoki [2] said the diatoms present indicates there is high silica in the river. In this study, we didn't see silica concentration.

We founded several spesies that indicated the Sinamar River has been contaminant. There are Lyngbya, Oscillatoria, Cymbela dan Pinnularia. These spesies life from lightly ( $\alpha$-mesosaproba) to heavy contaminant (polisaproba). We suggest that they presented have describe that Sinamar River has been contaminant.

Diversity index are decreasing from station 1 to station 8 . In the upstream (station 1) the diversity index is 2,75 and in the downstream (station 2) decreasing into 2,51. It is mean the periphyton's diversity is decreasing in the downstream. Diversity index indicates the periphyton's diversity, the higher diversity that means the water quality in the good condition.

The diversity index and saprophyte index are present in Table II. 
TABLE II:

PERIPHYTON'S DIVERSITY INDEX AND SAPROPHYTE IINDEX

\begin{tabular}{|c|c|c|c|}
\hline Stations & $\begin{array}{c}\text { Diversity } \\
\text { Index }\end{array}$ & $\begin{array}{c}\text { Saprophyte } \\
\text { Index }\end{array}$ & $\begin{array}{c}\text { Water Quality } \\
\text { Criteria }\end{array}$ \\
\hline Station 1 & 2,75 & 1,00 & $\begin{array}{c}\text { Lightly } \\
\text { contaminant }\end{array}$ \\
\hline Station 2 & 2,61 & 0,87 & $\begin{array}{c}\text { Lightly } \\
\text { contaminant }\end{array}$ \\
\hline Station 3 & 2,69 & 1,00 & $\begin{array}{c}\text { Lightly } \\
\text { contaminant }\end{array}$ \\
\hline Station 4 & 2,63 & 1,31 & $\begin{array}{c}\text { Lightly } \\
\text { contaminant }\end{array}$ \\
\hline Station 5 & 2,61 & 1,00 & $\begin{array}{c}\text { Lightly } \\
\text { contaminant }\end{array}$ \\
\hline Station 6 & 2,59 & 0,89 & $\begin{array}{c}\text { Lightly } \\
\text { contaminant }\end{array}$ \\
\hline Station 7 & 2,55 & 0,87 & $\begin{array}{c}\text { Lightly } \\
\text { contaminant }\end{array}$ \\
\hline Station 8 & 2,51 & 0,86 & $\begin{array}{c}\text { Lightly } \\
\text { contaminant }\end{array}$ \\
\hline
\end{tabular}

The saprophyte indeks is about $0,86-1,31$. This indicate is The Sinamar River has lightly contaminant.

Physic and chemistry water quality parameters has presented in table III.

DO is about 6,72 to $8,33 \mathrm{ppm}$. These are high concentrations. This indicates the river in a very good condition. And then we see $\mathrm{BOD}_{5}$ is low, about 0,27-1,60 ppm. COD is low too. According to Indonesian Goverment's Regulation (IGR) no 82/2001, these parameters still in range of it.

The other paramters, Nitrate, Amoniac, and Phospate are low, still in the range. Also do TSS and $\mathrm{pH}$.

All of paramaters are in the good condition. It can be taking the water sample in the rainy season. It can be bleaching and make the value is low.

We can see there is opposite between physic and chemistry, and biology. It is confirm that the periphyton give a clearly result than others..

TABLE III:

WATER QUALITY OF SINAMAR RIVER

\begin{tabular}{|c|c|c|c|c|c|c|c|c|}
\hline \multirow{2}{*}{ Stations } & \multicolumn{9}{|c|}{ Parameters } \\
\cline { 2 - 9 } & DO $(\mathrm{ppm})$ & $\begin{array}{c}\text { BOD } 5 \\
(\mathrm{ppm})\end{array}$ & $\begin{array}{c}\mathrm{COD} \\
(\mathrm{ppm})\end{array}$ & $\begin{array}{c}\text { Nitrate } \\
(\mathrm{ppm})\end{array}$ & $\begin{array}{c}\text { Amoniac } \\
(\mathrm{ppm})\end{array}$ & $\begin{array}{c}\text { Phospate } \\
(\mathrm{ppm})\end{array}$ & $\begin{array}{c}\text { TSS } \\
(\mathrm{ppm})\end{array}$ & $\mathrm{pH}$ \\
\hline 1 & 8,33 & 0,27 & $-{ }^{*}$ & 0,06 & $<0,014$ & 1,43 & - & 7,32 \\
\hline 2 & 7,53 & 0,14 & - & 0,15 & $<0,014$ & 0,07 & - & 7,37 \\
\hline 3 & 8,02 & 1,08 & 2,4 & 0,05 & $<0,014$ & 0,35 & - & 7,31 \\
\hline 4 & 7,04 & 1,60 & - & 0,57 & 0,045 & 1,18 & 0.074 & 6,52 \\
\hline 5 & 6,88 & 0,64 & 0,8 & 0,66 & $<0,014$ & 0,86 & 0,091 & 6,56 \\
\hline 6 & 6,72 & 0,80 & 10,4 & 0,61 & $<0,014$ & 0,70 & 0,163 & 6,76 \\
\hline 7 & 6,88 & 0,48 & 7,2 & 0,49 & 0,035 & 0,55 & 0,058 & 6,65 \\
\hline 8 & 7,04 & 0,48 & 5,6 & 0,55 & 0,079 & 0,49 & 0,090 & 6,79 \\
\hline
\end{tabular}

Description: $*$ ) $=$ not detected / very small

\section{IV.CONCLUSION}

The conclusion is Sinamar River has been lightly contaminant according to periphyton's structure.

\section{ACKNOWLEDGMENT}

The authors would like to thank to Indonesian Ministry of Research, Technology and Higher Education and Payakumbuh Agricultural Polytechnic.

\section{REFERENCES}

[1] Oxborough, K. and N.R. Baker. 1997. Resolving chlorophyll a fluorescence images of photosynthetic efficiency into photochemical and nonphotochemical components-calculation of $q P$ and $F v 0 / F m 0$ without measuring Fo-. Photosynthesis Research 54: 135-142.

[2] Ekwu, A.O. and F.D. Sikoki. 2006. Phytoplankton diversity in the cross river estuary of Nigeria, Journal of Applied Sciences \& Environmental Management 10 (1): 89-95.

[3] Effendi, H, M. Kawaroe, D.F. Lestari, Mursalin, T. Permadi. 2016. Distribution of phytoplankton diversity and abundance in Mahakam Delta, East Kalimantan. The $2^{\text {nd }}$ International Symposium on LAPAN-IPB Satellite for Food Security and Environmental Monitoring 2015, LISAT-FSEM 2015. Procedia Environmental Science, 33: $496-504$.

[4] Nassar, M.Z, H. R. Mohamed, H. M. Khairy, S. H. Rashedy, 2014. Seasonal fluctuation of phytoplankton community and physico-chemical paramters of the north western part of the Red Sea, Egypt . Egyptian Journal of Aquatic Research 40: 395-403.

[5] Eyo, V.O, P,B. Ekpo, A.B Andem, K.A Okorafor, 2013. Ecology and Diversity of Phytoplankton in the Great Kawa River, Cross River State, Nigeria. International Journal of Fisheries Nad Aquatic Studies 1(2): 1-7.
[6] Ekawaty, R dan Harmailis, 2013. Microalgae Periphyton's Diversity as Water Quality Bioindicator of Batang Agam River Payakumbuh. Proceeding International Seminar. ISBN 978-979-98691-4-2. Payakumbuh.

[7] Badsi, H, H.O Ali, M. Loudiki, and A. Aamiri. 2012. Phytoplankton Diversity and Community Compotion along the Salinity Gradient of The Massa Estuary. American Journal of Human Eology Vol 1 No 2 2012. $58-64$

\section{BIOGRAPHIES}

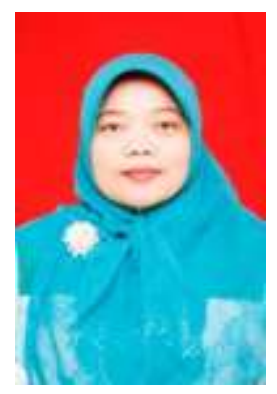

Reni Ekawaty, was birth in Padang, West Suamtera Indonesia, on July 23 1976. 1999 passed on Biology Department, Andalas University. And countiniued to Bogor Agricultural University, and passed as Master Degree in 2001 at Natural Resources and Environmental Management. Now, active as Lecturer at Agricultural Water Management Study Program, Payakumbuh Agricultural Polytechnic, West Sumatera Indonesia, since 2002. The concern in water quality and environment

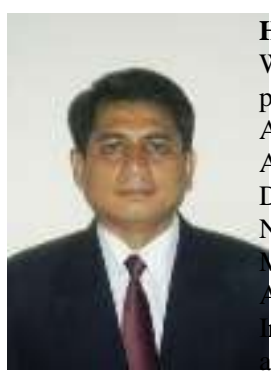

Harmailis, was birth in Ujung Gading Pasaman, West Sumatera Indonesia, on July 16 1969. 1992 passed on Agricultural Technology Department, Andalas University. And countiniued to Bogor Agricultural University, and passed as Master Degree in 2000 at Agricultural Technology. Now, active as Lecturer at Agricultural Water Management Study Program, Payakumbuh gricultural Polytechnic, West Sumatera ndonesia, since 1994. The concern in gricultural technology 


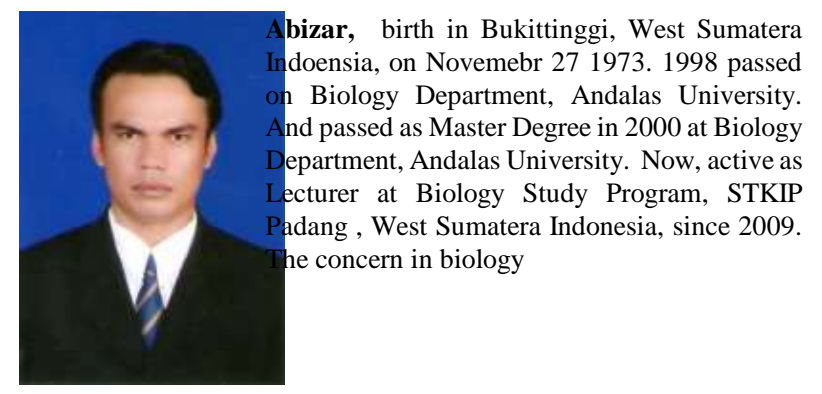

